\title{
MULTI-CRITERIA APPROACH FOR DESIGNING SUSTAINABLE DRAINAGE IN MALANG RESIDENTIAL AREA INDONESIA
}

\author{
HAPSARI, Ratih Indri ${ }^{1 *}$, MUNTAHA, Yasnuar ${ }^{1}$, EFENDI, Medi ${ }^{1}$ \\ ${ }^{1}$ Department of Civil Engineering, State Polytechnic of Malang \\ Jl. Soekarno Hatta 9, Malang 65141 - INDONESIA \\ *Corresponding author: ratihindri@gmail.com
}

\begin{abstract}
Environmentally sound approach for sustainable urban drainage could promote infiltration and lower the risk of flooding. This study presents the framework to evaluate the drainage alternatives considering multiple aspects including water quantity, life cycle cost and amenity. This approach is verified through application at a residential area in Malang city Indonesia. Different combinations of drainage components comprising of drainage channels, infiltration wells and biopore absorption holes are assessed regarding runoff reduction, present value of life cycle cost, and willingness to pay for the convenience. The first part describes the effective designs of sustainable drainage components in the houses as well as in the public spaces of the housing. The second part of this study describes the use of analytic hierarchy process for weight assignment of sustainability criteria and multiple benefit calculation. The study recommends infiltration wells and biopore absorption holes together with drainage channels as the best management practice of sustainable drainage system based on its overall sustainability index.
\end{abstract}

Keywords: Sustainable drainage system; multi-criteria; AHP.

\section{INTRODUCTION}

The rapid urban growth faces many challenges related to water security. The change of land use from the pervious to impervious cover degrades the retarding function. The risk of flooding rises as the flood peak turns into the higher magnitude and the flood lag time becomes shorter. The decreasing of permeable catchments inhibits the water infiltration and results in a reduction of groundwater recharge. Nowadays, the paradigm of stormwater management in an urban area has switched from the traditional approach which conveys the runoff immediately to the natural water body, to the environmentally sound approach. In the new paradigm, the excessive stormwater is controlled by promoting the infiltration for ground water conservation (Butler \& Parkinson, 1997; Charlesworth, 2011).

Porous pavement, rainwater harvesting, green roof, wetland, detention pond, retention facilities, soakaway, drainage well, filter drain, filter infiltration trench, permeable surface, water storage, swale and wetland as the most popular sustainable drainage infrastructures (Charlesworth, 2011; Zhou, 2014), is possible to be applied in order to substitute or complement the conventional drainage using channels or pipes. The use of these innovative designs necessitates multidiscipline approaches (Zhou, 2014), which considers not only the technical aspect, but also environmental, social, health and economic issues. The evaluation should also take into account the longterm performance of the designs options combining two or more constructions. The system is expected to utilize less resource with efficient cost and deliver the maximum benefits regarding water quantity, quality and amenity (Ellis et al., 2004).

Some advanced researches about multi-criteria decision support system for selecting the optimal sustainable drainage alternatives have been developed by researchers, which uses matrix (Ellis et al., 2006), tradeoff comparison (Chow et al., 2014), direct comparison (Kennedy et al., 2007) and operation research approaches. In the latter methods, fuzzy principles, analytic hierarchy process (AHP), value engineering, weighted average and outranking techniques are some of the widely used techniques in the engineering field. Martina et al. (2007) applied Electre outranking technique for best management practices in drainage. A generic performance criterion together with benchmark and thresholds approach was used by Ellis et al. (2004) for selecting the optimal solution of urban and highway runoff treatment. AHP has been utilized for weighting the criteria in evaluating sustainable transport solutions (Awasthi \& Chauhan, 2011), agricultural development (Moghaddam \& Karami, 2008) and solid waste management (Pires et al., 2011). However, the use of AHP for decision making in sustainable drainage management is very limited to the studies conducted by Dong et al. (2008a), Dong et al. (2008b) and Benzera et al. (2012).

Over the years, Indonesia has seen many flood disasters that have brought about great losses (Hapsari $\&$ Zenurianto, 2016). With 30\% increasing of municipal water demand in 2015 and flooding problem in 
many regions, promotion of stormwater infiltration through the construction of a million biopore absorption holes is set on Malang development agendas. A case study in Araya City III residential area in Malang, Indonesia is presented to describe the framework. This new housing space is considered significant as it is a part of buffer zone of Malang urban city, Indonesia. Malang regency which surrounds the Malang metropolitan area is designed as the buffer area of the city serving the environment conservation and development. Taking into account the local physical features, topography and zoning regulation, the selected sustainable drainage components are infiltration wells and biopore absorption holes supplementing traditional drainage channels.

This paper presents the quantitative way to evaluate the sustainability of drainage components combination using multi-criteria approach. The practical designs of drainage channels, infiltration wells and biopore in Araya City Malang are described. By the proposed approach, the research subsequently aims at evaluating the most beneficial options of the sustainable drainage solutions combining these three components. The criteria to assess the total benefit are the water quantity of reduced runoff representing the technical aspect, life-cycle net present values to include the financial aspect and public perception on amenity as the representation of social aspect. The weights of these criteria are determined using AHP based on expert opinion. The cross-comparison of the benefits between the design combination alternatives could suggest the most advantageous option with maximum multiple advantages.

\section{METHODOLOGY}

\section{Case Study Area}

The framework is evaluated through the application in a case study area of Araya City III residential area $(7.927951 \mathrm{~S}$ to $7.937812 \mathrm{~S}$ and $112.675894 \mathrm{E}$ to 112.960914E) as depicted in Figure 1. The planning scheme area covers an area of about 66.91 hectares. Two tributaries of Bango River locate in the left and right boundary of the area. Figure 1 middle panel shows the situation map of the study area. The elevation ranges from 509 AMSL in the north part and 475 AMSL in the south part. The right-hand-side of Figure 1 exposes the site plan and topographical map. There are 1306 units of the houses accommodated in this area.

Ten-year historical daily rainfall records from Singosari, Ciliwung and Tumpang rain gauges from 2005 to 2014 provided by Water Resources Bureau of Malang Regency are available for analyzing the stormwater runoff rates with five years return period.
Hourly rainfall intensity data is obtained from JAXA Global Rainfall Watch-GSMAP (Global Satellite Mapping of Precipitation). This data is required for analyzing the absorption rate through the biopore absorption holes.

To ensure the type of the soil which allows infiltration, cone penetrometer test (CPT) in the housing area was conducted to determine the delineating soil stratigraphy. As stated by Gill et al. (2007), soil type is an important determinant of the infiltrating rate. The runoff rate is lower on high infiltration soil such as sandy soil and higher on low infiltration soil like clay soil, and conversely for the infiltration rate. Figure 2 illustrates the results of CPT test overlaid with soil classification chart (Bowles, 2001). Omitting soil layer deeper than $2.4 \mathrm{~m}$, soil type is categorized as silty clay or clayey silt. Along with this, investigation on the residential wells was conducted to get information on the groundwater depth. The survey of the ten wells during the rainy season of 2016 reveals that the groundwater level ranges from $18 \mathrm{~m}$ to $20 \mathrm{~m}$. Considering the relatively impermeable soil type and the sufficiently deep ground water level, the infiltration and detention facilities are feasible as a sustainable drainage system.

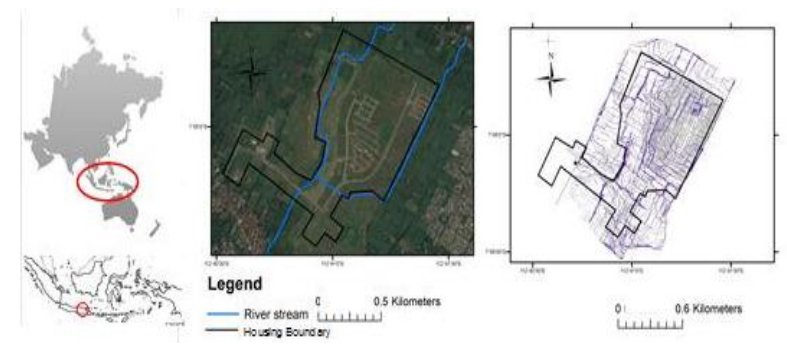

Source: PT. Araya Bumi Megah

Figure 1. Study area (left), situation map (middle), site plan and topographical map (right)

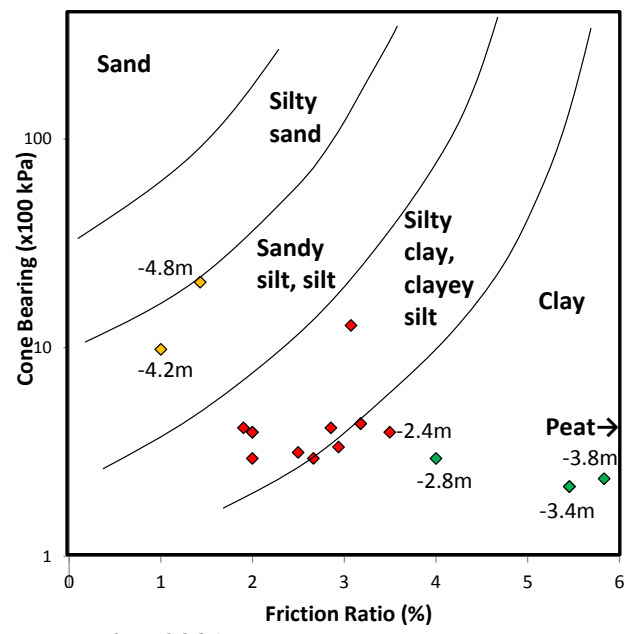

Source: Bowles, 2001.

Figure 2. Plots of soil type from CPT results 


\section{Hydrological Analyses}

The rational method is a tool to analyze storm drain design from relatively small drainage area or less than 100 hectares (ASCE, 1996). The following formula calculates the peak runoff discharge:

$Q_{T}=k C i_{T} A$

Where:

$Q_{T}=$ is the peak flow rate in $\mathrm{m}^{3} / \mathrm{s}$ for return interval $T$ years

$k=$ unit conversion factor of 0.00278 .

$C=$ is the runoff coefficient for the particular land use

$i_{T}=$ is the design precipitation intensity in $\mathrm{cm} / \mathrm{hr}$ for return period of $T$ years with duration equal to the time concentration for the basin

$A=$ is the catchment area in hectares

Rainfall frequency analysis is used for designing the stormwater control structures. Log Pearson Type III distributions is one of the widely utilized techniques (Millington et al., 2011). The estimator $X$ with particular time return or exceedance probability is:

$$
\log \left[X_{q}\right]=\overline{\mathrm{X}}+K_{q} S
$$

Where:

$\overline{\mathrm{X}}=$ sample mean

$S$ =sample standard deviation

$K_{q}=$ frequency factor dependent on the selected return period and data skewness.

This study uses five years recurrence interval as it is considered as minor drainage in the residential area (Chin, 2004). According to Kirpich (1940), the important concentration time formula in urban environment, the time travel ( $\mathrm{min}$ ) of from the most upstream point to the watershed outlet is defined as below:

$T_{C}=0.0078\left(\frac{\mathrm{L}^{2}}{\mathrm{~S}}\right)^{0.295}$

Where:

$L=$ length of channel from headwater to outlet ( $\mathrm{ft}$ )

$S=$ is average gully slope (ft/ft)

\section{Infiltration Well}

Stormwater drainage well is a construction to manage surface water runoff by allowing stormwater to infiltrate and percolate into the earth (US-EPA, 2003). This well is often called infiltration well, dry well, bored well, infiltration gallery, or even soakaway with various designs. According to US-EPA
(2003), a bored, drilled, or driven shaft whose depth is greater than the largest surface dimension; or, dug hole whose depth is greater than the largest surface dimension; or, an improved sinkhole; or, a subsurface fluid distribution system is categorized as a stormwater drainage well. Theoretically, volume and efficiency of infiltration well can be calculated by the water balance equation of well inflow and infiltrated water based on Darcy Law as follows (Sunjoto, 2008):

$$
H=\frac{Q}{F K}\left[1-e^{\frac{-F K T}{\pi R^{2}}}\right]
$$

Where:

$H=$ well water depth (m)

$Q=$ inflow discharge $\left(\mathrm{m}^{3} / \mathrm{s}\right)$

$F=$ geometric factor $(\mathrm{m})$

$K=$ hydraulix conductivity $(\mathrm{m} / \mathrm{dt})$

$T=$ dominant duration of precipitation

$R=\operatorname{well}$ radius $(\mathrm{m})$

The placement, design and specification of the well are planned by US-EPA standard (US-EPA, 2003) and Suripin (2004) adapted to the local condition.

\section{Biopore Absorption Hole}

Biopore absorption hole is vertical cylindrical hole beneath the ground filled up with organic compost to encourage the natural biopores growth. Biopores is soil pores and burrows that are formed through the activities of soil organisms and plants roots promoted by composting process. The biopores generate higher infiltration through the existence of the surface of infiltration which is defined as the area of holes. This technique is introduced by Brata (2008), and the number of required holes are (Rianawati et al., 2014):

$N=\frac{R A}{I}$

Where:

$n$ =number of holes

$R=$ hourly rainfall intensity $(\mathrm{mm} / \mathrm{hr})$

$A=$ area of infiltration surface $\left(\mathrm{m}^{2}\right)$

$I$ =infiltration rate $($ litre/hr)

For setting the biopore effectively, the placement, specification and maintenance scheme are planned with reference to Brata (2008).

\section{Framework of Multi-criteria Decision Making}

The study proposes framework of multi-criteria decision making to assist in deciding the most feasible and sustainable drainage system out of four scenarios 
combining drainage channels, infiltration wells and biopore absorption holes that maximize the multiple benefits. Further, this study refers an evaluation of combined designs performance from Chow et al. (2013). Upon reviewing researches on sustainable drainage system multi-criteria decision making, (Chow et al., 2013, Zhou, 2014) three criteria are taken as top indicator aggregation, namely quantity, cost and environment. The previous researchers determine indicators formulation of the system performances in numerous ways. In this study, we adopt Chow et al. (2013) method that uses runoff annual volume reduction in the $\mathrm{m}^{3}$ unit as an attribute of quantity. The stored water volume provided by each component is calculated through hydrological analyses. The costs incurred in the whole life of the facilities are the cost of constructions, operation and maintenance (Chow et al. (2013) and depreciation. After the effective placement, shape and dimension of the constructions have been designed, the annual unit costs can be calculated in IDR unit. This study demonstrates the life-cycle cost of the systems for 30 years useful life.

The perceived value of the amenity resource with reducing the flood and availability of the drainage infrastructures represents the environment indicator. Amenity value was considered as a secondary benefit of sustainable drainage systems. However, this aspect is important in recent drainage solutions as it establishes the balance of the overall benefits and embraces the other important aspects of urban water management more deliberately. This research adopts the method proposed by Ready et al. (1997) namely contingent valuation approach. The parameter to ascertain amenity is public willingness to pay (WTP) for inundation countermeasures, which is defined as the respondent's preferences or willingness to trade an increased cost of living or property investment to avoid inundation and flooding in the housing area (DEFRA, 2005) in IDR unit. The inconveniences due to the presence of the constructions as well as the necessary periodic maintenance works are also mentioned in the questionnaire. Questionnaire is administered to obtain the public perception in WTP targeting the residents of upscale real estates in Malang City. Simple random sampling technique is used to select 100 households.

According to Ellis et al. (2006), weightings can be applied to reflect the importance of each criterion and/or indicator. The weights of the three benefit criteria are determined using analytic hierarchy process (AHP) based on expert opinion. AHP is a structured technique for organizing and analyzing complex decisions (Saaty, 1980). It represents a decision-making problem by a hierarchical structure constituted by its components. First, the pairwise comparison of the components relying on the judgments of experts is carried out by involving a hydrologist (contributor 1), a resident of upper-level real estate (contributor 2), local environment agency (contributor 3) and real estate developer entrepreneur (contributor 4). The priority scales are derived and then the scales are synthesized by multiplying them by the priority of their parent. The results of the pairwise comparisons are arranged in a matrix. The first normalized right Eigen vector of the matrix is the dominant one. These values are then determined by the ratio scale or weighting.

The performance matrix is employed to determine the sustainability indices of drainage systems combination. As three parameters measure the sustainability in a different unit, it is required to normalize the values of each parameter to have dimensionless variable before coupling (Eboli and Mazzulla, 2013). Parametric calculation by multiplying the weights with the individual combination values is done to evaluate the total scenarios sustainability index (Hassan et al., 2012, Eboli and Mazzulla, 2013).

\section{RESULTS and DISCUSSION}

\section{Effective Design of Drainage Channels, Infiltra- tion Well and Biopore Absorption Holes}

Two primary drainage channels are intended to convey the storm water from the housing to the rivers located in the left and right side of the housing area as depicted in Figure 3 left side. The time concentrations of the catchments area are 0.24 hours and 0.27 hours for the left catchment and the right catchment respectively. With design rainfall of $109.276 \mathrm{~mm}$, the rainfall intensities at the concentration time are $0.00003 \mathrm{~m} / \mathrm{s}$. The average runoff coefficient for the entire watershed made up of $75 \%$ impermeable surface, and $25 \%$ permeable surface is 0.6 . The design flood for left channel is $5.69 \mathrm{~m}^{3} / \mathrm{s}$ and for right channel is $4.89 \mathrm{~m}^{3} / \mathrm{s}$ conveying $10.58 \mathrm{~m}^{3} / \mathrm{s}$ water to Bango river. The design of the channels geometric shape is circular culvert type for the sake of safety and convenience. Figure 3 right side shows the typical drainage cross-section shape which is placed under the pedestrian line.

The infiltration well is placed in the backyard of each house. It is assumed to collect rainwater that falls on the roof. Downspout and conveyance pipe are designed to drain the water from the gutter to the well. The catchment area is the roof surface with the design as illustrated in Figure 4. With the design rainfall of 
$109.276 \mathrm{~mm}$, the rainfall intensities within 0.006 hours concentration time is $0.0003 \mathrm{~m} / \mathrm{s}$ resulting $0.04 \mathrm{~m}^{3} / \mathrm{s}$ design discharge. Subsequently, the depth of the well is calculated at a given diameter of $1 \mathrm{~m}$. Silt and loess soil has permeability rate of $1 \mathrm{~m} / \mathrm{d}$ to $0.01 \mathrm{~m} / \mathrm{d}$ as stated by FAO (1980). According to Suripin (2004), silt-loam soil type is categorized as middle permeability, and the permeability rate is $2 \mathrm{~cm} /$ hour to 6.5 $\mathrm{cm} /$ hour. The average value of $0.00002 \mathrm{~m} / \mathrm{s}$ is taken in this analysis. The calculation by using Equation 1.4 results the well depth ranges from $0.3 \mathrm{~m}$ to $1.1 \mathrm{~m}$ varied with housing roof size with the same absorption rate of $0.000071 \mathrm{~m}^{3} / \mathrm{s}$. For 1306 houses, there will be the same number of well in the whole housing area.
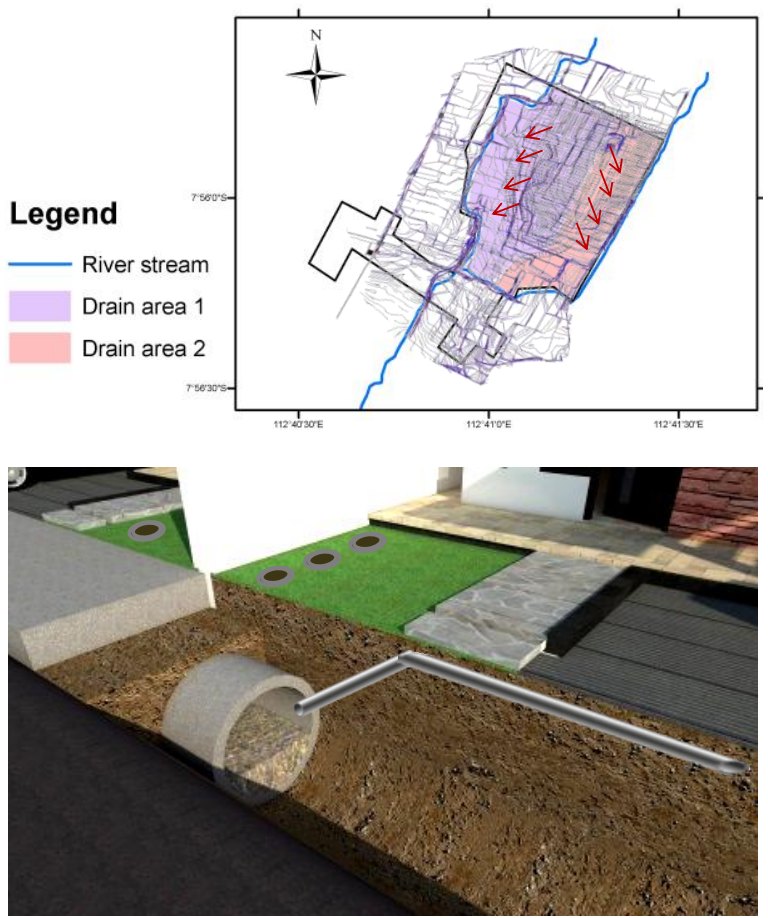

Figure 3. Drainage primary channels and catchment areas (left) and typical drainage cross section shape (right)
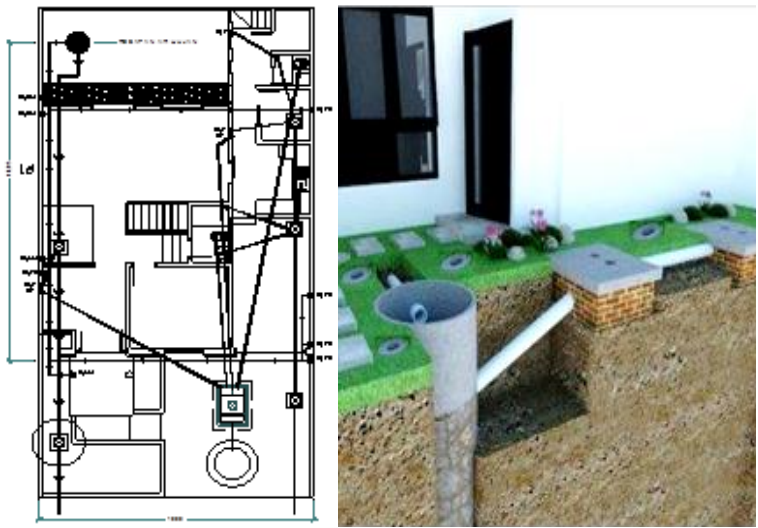

Figure 4. Layout of infiltration well (left) and the design (right)
The biopore absorption holes are installed in the green spaces, i.e. front garden and backyard of each house, also public parks of the real estate. The diameter of the holes is $10 \mathrm{~cm}$ and the depth is $1 \mathrm{~m}$. The predominant daily rainfall intensity is analyzed in based on the rainfall with $20 \%$ annual exceedance probability. By analyzing the historical rain data, the designated rain occurred at the rate of $135 \mathrm{~mm} /$ day in the year 2013. The maximum hourly rainfall intensity during this event was $7.17 \mathrm{~mm} / \mathrm{h}$. According to FAO (Brouwer, 2001), basic infiltration rate for clay loam and loam ranges from $5 \mathrm{~mm} /$ hour to $20 \mathrm{~mm} / \mathrm{hour}$. Here, the average rate of $12.5 \mathrm{~mm} / \mathrm{hour}$ is taken meaning that every square meter could infiltrate 12.5 liters of rainwater within an hour. It is found that the number of required holes for one house is from 3 to 11 in the front garden and 8 to 13 in the backyard depending on the house type and size. Meanwhile, the $54,769 \mathrm{~m}^{2}$ real estate park requires 31,398 biopore absorption holes. The holes placement should be set in such a way that prevents blockage due to human activities. To enable better storm water collection, the holes are placed in the depressed points, i.e. in the garden lines and around the trees. Figure 5 shows the practical design of biopore absorption hole.
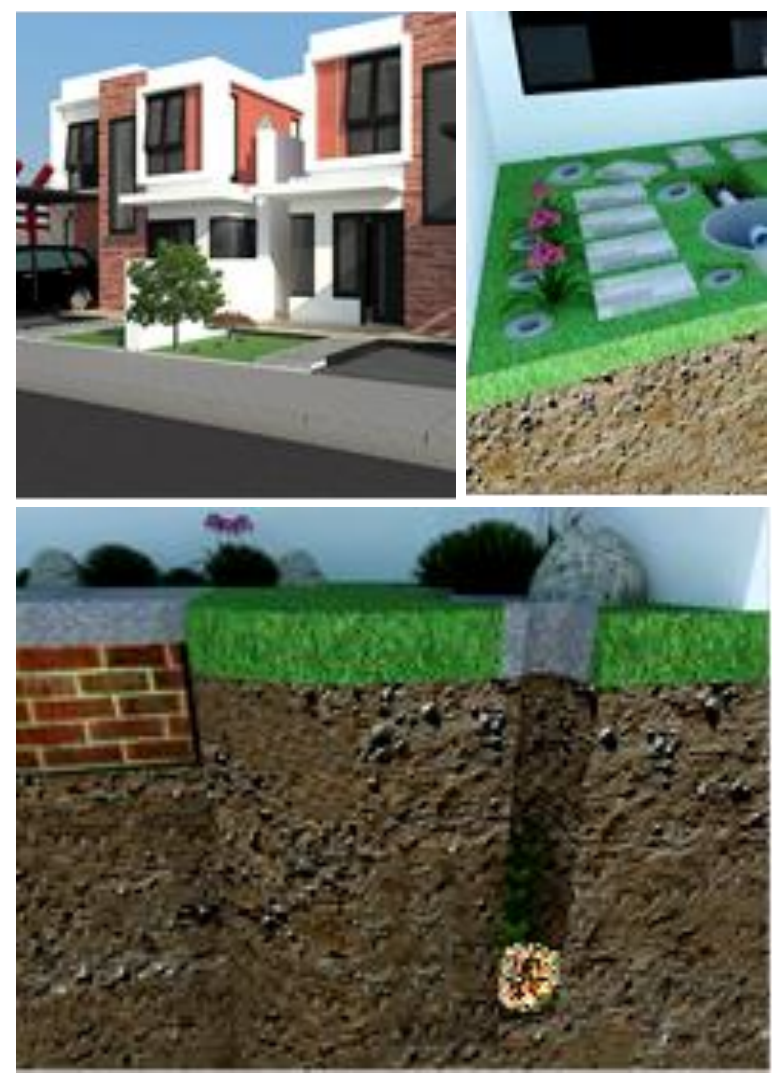

Figure 5. Layout of biopore absorption hole in the front yard (left), in the backyard (middle) and the detail design (right) 


\section{Benefits of Runoff Reduction}

The elements of water balance i.e. precipitation and surface runoff are converted from $\mathrm{mm} / \mathrm{h}$ or $\mathrm{m}^{3} / \mathrm{s}$ into annual volume unit. Table 1 shows the volume of water for $669,160 \mathrm{~m}^{2}$ catchment area. It shows that the percentage of runoff is about $60 \%$ meaning that the current pavement is assumed can infiltrate water as much as $40 \%$ of the rain. Subsequently, the value of the additional amount of reduced runoff for each scenario is calculated. On this parameter, the highest reduced runoff is given by providing all sustainable drainage elements, followed by drainage channel and infiltration well. The infiltrated water from infiltration wells contributes to the runoff reduction with the insignificant amount. As stated in Indonesian Standard of Infiltration Well Design (SNI 06-2405-1991, 1991), this method is effective in reducing runoff and increasing groundwater recharge for the area with the hydraulic conductivity of $0.00001 \mathrm{~m} / \mathrm{s}$ or more. Yet, this housing has been constructed in low permeability soil with slightly higher hydraulic conductivity rate than the value suggested by Suripin (2004). The biopore absorption hole appears to be more effective in reducing flood, though all infiltrated water through this construction does not directly contribute to groundwater recharge.

Tabel 1. Volume of water for each element of water balance in the whole area

\begin{tabular}{lr}
\hline \multicolumn{1}{c}{ Elements } & Volume ( $\mathbf{m}^{3} /$ year $)$ \\
\hline Precipitation & $556,343,764$ \\
Surface runoff without sustainable & \\
$\quad$ drainage system & $333,806,259$ \\
Infiltrated water from infiltration wells & 291,878 \\
Infiltrated water from biopore & \\
$\quad$ absorption holes & $6,534,632$ \\
\hline
\end{tabular}

\section{Amenity Value}

The distribution of the respondents answer about the preferred WTP for avoiding the inundation impact on property, physical and mentally aspect damage is shown in Figure 6. The amenity value delivered by total sustainable drainage system proposed in this study gives WTP rate of $3,466,667$ IDR. This value is the highest among the other two single systems. The WTP for providing infiltration well is 2,800,00 IDR/household per annum and for providing biopore absorption hole is 2,933,333 IDR/household per annum. Given that infiltration well is designed to reduce the house gutter discharge and simultaneously promote the groundwater recharge, people are slightly more likely to choose biopore absorption hole, which can directly reduce the inundation in the house yards as well as in the real estate public spaces. Nevertheless, the presence of both sustainable drainage facilities is highly desired by the public.

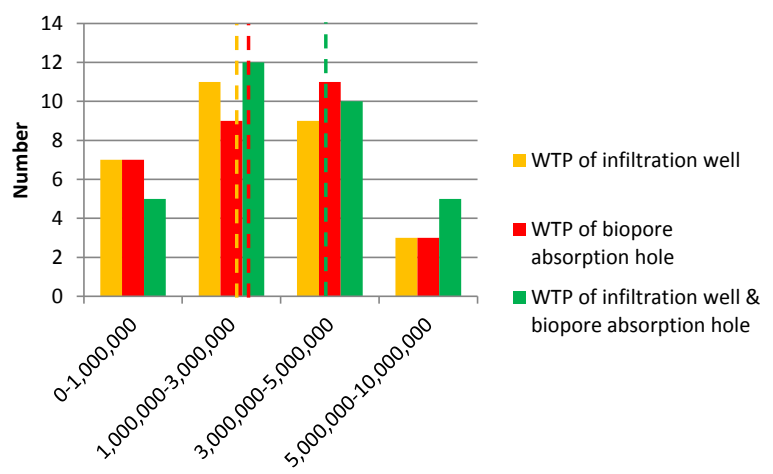

Figure 6. Distribution of WTP for one household. The broken lines indicate the average WTP value for each option.

\section{Life-cycle Costs}

In accordance with the proposed design depicted in Figure 4 and Figure 5, the average estimated capital expenditures of construction material, labor and equipment for one unit infiltration well is 6,386,030 IDR to $9,719,621 \mathrm{IDR}$. As for the biopore absorption hole, the cost per unit is $46,612 \mathrm{IDR}$, which shows that the initial cost of the infiltration well is much higher than that of the biopore absorption hole. The necessary maintenance of infiltration well is regular checking, cleaning and repair of the construction components. In biopore absorption hole, the degraded compost needs to be replaced with fresh compost regularly. The main resource required for the regular maintenance of these sustainable drainage systems is workforce. All the maintenance are performed every six months. Also, the constructions might need replacement once in 15 years for the infiltration well and in 5 years for the biopore absorption holes. One maintenance cycle expenditures are 10,589 IDR and 2,267 IDR for one unit infiltration well and biopore absorption hole respectively. The annual costs yielding from the obsolescence calculated by using straight line method are 212,460,958 IDR for infiltration well and 265,321,870 IDR for biopore absorption holes in all housing.

Dashed lines in Figure 7 demonstrate how the maintenance and replacement of biopore absorption hole consume higher expenses than those experienced from infiltration well. The reason is that the holes need a more frequent replacement for its small size and possibility of being trampled. Finally, by summing up all financial measures of the long-term cost and applying a discount rate, the cumulative 
present value would be obtained (solid lines in Figure 7). The estimation of drainage system costs after all sustainable components are applied gives discounted life cycle cost of 40,491,431,525 IDR. The estimated cumulative present value of involving infiltration well only is $24,520,677,133 \mathrm{IDR}$, while that of biopore absorption hole is $15,970,754,392$.

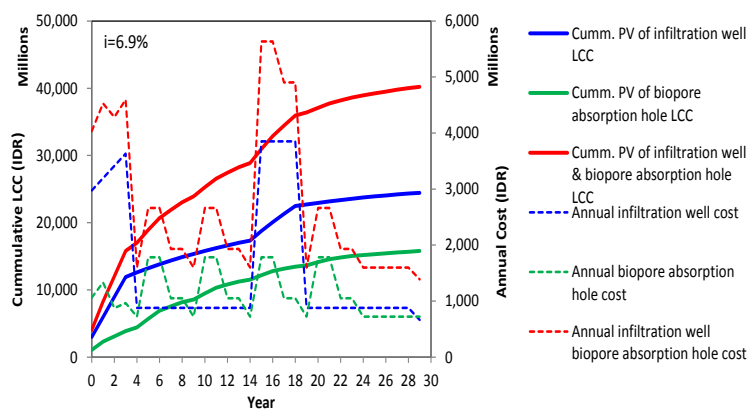

Figure 7. Discounted cash out of life cycle cost/LCC (solid lines) and annual expenditures (dashed lines)

\section{Multi-criteria Evaluation}

In Figure 8, the individual dimensionless values of sustainable drainage alternatives reviewed from three indicators are shown. Higher score indicates better performance. Similar performance has been confirmed in applying biopore absorption hole only and biopore absorption hole combined with infiltration well. By incorporating the performance scores with the numerical priority of the criteria given by AHP analysis, the best scenario can be recommended on the basis of sustainability index.

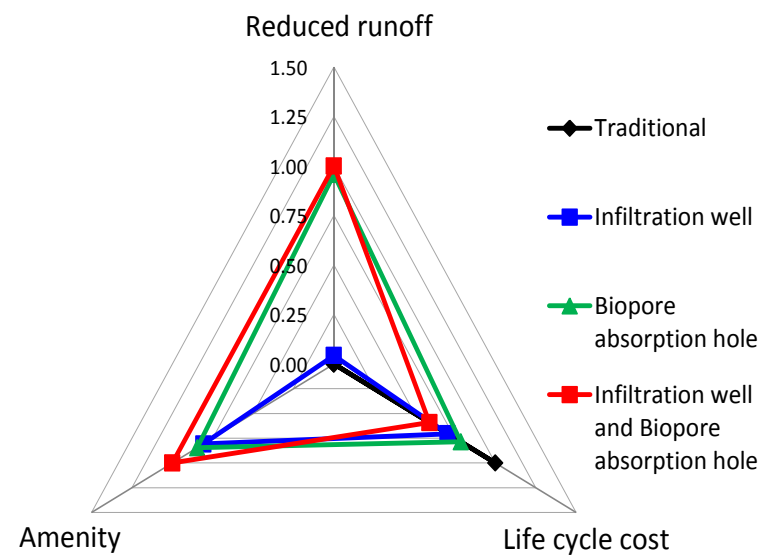

Figure 8. Individual alternatives scores (normalized) in terms of three criteria

Table 2 summarizes the importance analysis of three criteria through cross comparison from four contributors which shows a clear difference in the importance assigned by the contributors. Contribu- tors' answers on the perceived criteria importance are related to their role and knowledge of the sustainable drainage systems context. The hydrologist tends to put emphasize on water conservation. Similarly, the runoff reduction is also mainly selected by the environment agency as the important factor, in addition to amenity. By contrast, the runoff reduction criterion is less marked by the resident. For resident as the end user in upper-level housing, the convenience of the house and the public facilities is mainly perceived as the most important consideration in their purchasing decision. Meanwhile, the crucial factor for the enterprise is not the water conservation, but rather the total expenditure. The respondents appear to have considered all three criteria in reviewing the indicator of sustainable drainage systems, except the environment agency (contributor 3) who seems rule out the cost consideration to construct the facilities. It is because in the environmentalist perspective, protecting the environment generates economic benefits in long terms (Turner and Daily, 2008) which could largely compensate for the construction expenditure.

Table 2. Importance matrix of the criteria. Notes in the parentheses show the level of the difference of importance judged by the contributors.

\begin{tabular}{|c|c|c|c|}
\hline $\begin{array}{l}\text { Relative } \\
\text { Importance }\end{array}$ & $\begin{array}{l}\text { Runoff reduction } \\
\text { vs. } \\
\text { Life cycle cost }\end{array}$ & $\begin{array}{c}\text { Runoff } \\
\text { reduction vs. } \\
\text { Amenity }\end{array}$ & $\begin{array}{l}\text { Life cycle } \\
\text { cost } \\
\text { Amenity }\end{array}$ \\
\hline Contributor 1 & $\begin{array}{l}\text { Runoff reduction } \\
\text { (Strong important }\end{array}$ & $\begin{array}{l}\text { Runoff } \\
\text { reduction } \\
\text { (Moderate } \\
\text { important) }\end{array}$ & $\begin{array}{l}\text { Life cycle } \\
\text { cost } \\
\text { (Strong } \\
\text { important) }\end{array}$ \\
\hline Contributor 2 & $\begin{array}{l}\text { Life cycle cost } \\
\text { (Moderate } \\
\text { important) }\end{array}$ & $\begin{array}{l}\text { Amenity } \\
\text { (Strong } \\
\text { important) }\end{array}$ & $\begin{array}{l}\text { Amenity } \\
\text { (Moderate } \\
\text { important) }\end{array}$ \\
\hline Contributor 3 & $\begin{array}{l}\text { Runoff reduction } \\
\text { (Very strong } \\
\text { important) }\end{array}$ & $\begin{array}{l}\text { Runoff } \\
\text { reduction } \\
\text { (Moderate } \\
\text { important) }\end{array}$ & $\begin{array}{l}\text { Amenity } \\
\text { (Strong } \\
\text { important) }\end{array}$ \\
\hline Contributor 4 & $\begin{array}{l}\text { Life cycle cost } \\
\text { (Moderate } \\
\text { important) }\end{array}$ & $\begin{array}{l}\text { Amenity } \\
\text { (Moderate } \\
\text { important) }\end{array}$ & $\begin{array}{l}\text { Life cycle } \\
\text { cost } \\
\text { (Moderate } \\
\text { important) }\end{array}$ \\
\hline
\end{tabular}

Based on these results, a consolidated matrix integrating four matrices of importance is arranged. The normalized Eigen-vectors are then calculated, which shows the rank of importance of each criterion (Table 3). It clearly illustrates the fact that the prime potential criteria accommodating different contributor perspective are runoff reduction, followed by amenity and life cycle cost with the percentage of $35.66 \%$, $29.67 \%$, 34.67\% respectively. Runoff reduction delivers comparable importance value with amenity, 
which implies that the respondents consider both criteria to be an essential point in determining the best sustainable drainage scenarios. The slightly higher value of runoff reduction may be because the reduced runoff quantity simultaneously enables further benefits, such as groundwater recharge, biodiversity conservation, including urban amenity improvement. Research finding of Loc et al. (2015) also suggests that flood reduction benefit is the dominant criterion to judge the sustainable drainage feasibility.

Table 4 provides the sustainability indices of sustainable drainage designs options. The comparison shows that the traditional and sustainable drainage systems are associated with a large difference in the total sustainable index generally. It is consistent with the recommendation from Kennedy et al. (2007) who reviews the extensive benefits of a sustainable drainage system which go beyond the advantages of traditional drainage solutions. In addition, Chow (2014) presents an example of how this approach is better in achieving sustainable performance in Yarralumla, Australia. The use of infiltration well in the system proposed in Scenario 2 has proven ineffective for delivering the overall objective, particularly due to the less-permeable ground condition. The Scenario 3 experiences comparable levels of sustainability index with Scenario 4. This part suggests that for this study site, the inclusion of the biopore absorption hole in the sustainable drainage system is advised. For its simplicity and low cost, this option enables affordable drainage system toward sustainability. Furthermore, having the sufficient numbers of the holes, the biorentention facilities in this area can significantly reduce the volume of direct runoff that drained to the channels by allowing the water to be absorbed into the earth. Nevertheless, the sustainable drainage design needs to address an issue relating to the groundwater recharge. Indeed, infiltration well is still an important facility for groundwater recharge. In regard to the matter, given that Scenario 4 demonstrates the highest sustainable index, this research offers the integration of drainage channels network, infiltration well and biopore absorption hole into the study area as the best management practice of sustainable drainage system.

Table 3. Matrix and Eigen-vectors of importance

\begin{tabular}{|c|c|c|c|c|}
\hline & $\begin{array}{l}\text { Runoff } \\
\text { reduction }\end{array}$ & $\begin{array}{c}\text { Life cycle } \\
\text { cost }\end{array}$ & Amenity & $\begin{array}{l}\text { Eigen- } \\
\text { vectors }\end{array}$ \\
\hline $\begin{array}{l}\text { Runoff } \\
\text { reduction }\end{array}$ & - & $12 / 5$ & $7 / 8$ & $35.66 \%$ \\
\hline $\begin{array}{l}\text { Life cycle } \\
\text { cost }\end{array}$ & $5 / 7$ & - & 1 & $29.67 \%$ \\
\hline Amenity & $11 / 7$ & 1 & - & $34.67 \%$ \\
\hline
\end{tabular}

Table 4. Performance matrix of sustainability indicators of four designs alternatives

\begin{tabular}{|c|c|c|c|c|c|c|}
\hline & \multirow{3}{*}{ Scenario } & \multicolumn{3}{|c|}{$\begin{array}{l}\text { Quantity of indicators } \\
\text { (normalized) }\end{array}$} & \multirow{3}{*}{$\begin{array}{c}\text { Total } \\
\text { sustai- } \\
\text { nable } \\
\text { index }\end{array}$} & \multirow{3}{*}{$\begin{array}{r}\text { Prio } \\
\text { rity }\end{array}$} \\
\hline & & $\begin{array}{l}\text { Runoff } \\
\text { reduction }\end{array}$ & $\begin{array}{c}\text { Life cycle } \\
\text { cost }\end{array}$ & Amenity & & \\
\hline & & $\begin{array}{l}\text { Weight: } \\
35.66 \%\end{array}$ & $\begin{array}{l}\text { Weight: } \\
29.67 \%\end{array}$ & $\begin{array}{l}\text { Weight: } \\
34.67 \%\end{array}$ & & \\
\hline 1 & Traditional & 0.00 & 1.00 & 0.00 & 0.28 & 4 \\
\hline 2 & $\begin{array}{l}\text { Infiltration } \\
\text { well }\end{array}$ & 0.04 & 0.71 & 0.81 & 0.53 & 3 \\
\hline 3 & $\begin{array}{l}\text { Biopore } \\
\text { absorption } \\
\text { hole }\end{array}$ & 0.96 & 0.79 & 0.85 & 0.87 & 2 \\
\hline 4 & $\begin{array}{l}\text { Infiltration } \\
\text { well and } \\
\text { biopore } \\
\text { absorption } \\
\text { hole }\end{array}$ & 1.00 & 0.59 & 1.00 & 0.90 & 1 \\
\hline
\end{tabular}

To date, urban drainage master plans in Indonesia are generally directed to collect and convey of stormwater from the urban area as quickly as possible to water bodies through pipes and channels. The results from this initial case study support the fact that is integrating sustainable drainage systems into the built environment is essential in improving water management practices in the housing area. In addition to infiltration purpose, sustainable urban drainage can be designed for a wide variety of purposes including water harvesting, pollutant reduction, flood attenuating and slow conveying. To evaluate in a more sustainable way, it is required to broaden the range of recognized benefits. Evaluation scheme in this case study has shown that the trade-offs between objectives can be complex and non-linear as more objectives are considered. This framework aids to deliver the sustainable drainage best practices in a more quantitative way to maximize multiple benefits.

\section{CONCLUSION}

This paper has demonstrated the framework for a multi-criteria approach to facilitate better management decision in evaluating the best practices of sustainable drainage. The method allows the quantitative way to effectively select the appropriate design combination by considering multiple benefits associated with water quantity, life cycle expenditures and amenity. The advantage of the framework is verified through a case study in Araya City III residential area in Malang, Indonesia. Independent valuation shows that combination of drainage culverts with infiltration wells and biopore absorption holes 
enables the highest performance in terms of amenity perceived by the residents and runoff reduction quantity among the four scenarios. On the other hand, this scenario would certainly incur the highest expenditure over the life cycle of 30 years. Analytic hierarchy process based on expert opinion has concluded the most important criteria is runoff reduction, followed by amenity and life cycle cost with the percentage of $35.66 \%, 29.67 \%, 34.67 \%$ respectively. Giving the highest sustainability index, infiltration well and biopore absorption hole supplementing the conventional drainage system is decided as the most recommended option. This study would be extended to address water quality issue in the multi-criteria assessment of sustainable drainage system using cost-benefit analysis. Further desired research is to include other sustainable drainage components across the built-up area of the city for managing surface water and groundwater recharge, which in turn would create wider benefits to people and water resources.

\section{ACKNOWLEDGMENT}

The authors would like to send the greatest grateful to PT. Araya Bumi Megah for giving a helpful channel for discussing and providing data for completion of the paper. In addition, the authors would like to thank Construction Management Laboratory, Civil Engineering Department, State Polytechnic of Malang in supporting this research.

\section{REFERENCES}

Awasthi, A. \& Chauhan, S.S. (2011). Using AHP and Dempster-Shafer theory for evaluating sustainable transport solutions, Environmental Modelling \& Software, 26(6), p.787-7960.

Benzerra, A., Cherrared, M., Chocat, B. \& Cherqui, F. (2012). Decision support for sustainable urban drainage system management: A case study of Jijel, Algeria, Journal of Environmental Management, 101, p.46-53.

Bowles, J.E. (2001). Foundation Analysis and Design, $5^{\text {th }}$ edition. The McGraw-Hill Companies, Inc., Singapore.

Brata, K.R. \& Nelistya. (2008). Lubang Resapan Biopori, ${ }^{\text {st }}$ edition, Niaga Swadaya, Jakarta.

Butler, D. \& Parkinson, J. (1997). Towards sustainable urban drainage, Water Science and Technology, 35(9), p.53-63.

Charlesworth, S.M. (2010). A review of the adaptation and mitigation of global climate change using sustainable drainage in cities, Journal of Water and Climate Change, 1(3), p.165-180.
Chin, D.A. (2004). An overview of urban stormwatermanagement practices in Miami-Dade County, Florida U.S., Geological Survey Open-File Report, 2004-1346.

Chow, J.F., Savić, D., Kapelan, Z., Fortune, D. \& Mebrate, N. (2013). Translating legislative requirements and best practice guidance into a systematic, multi-criteria decision support framework for effective sustainable drainage design evaluation, Proceedings of 2013 IAHR World Congress.

Chow, J.-F., Savić, D.A., Fortune, D., Kapelan, Z. \& Mebrate, N. (2014). Evaluating and optimizing sustainable drainage design to maximize multiple benefits: Case studies in China, Proceeding of $11^{\text {th }}$ International Conference on Hydroinformatics.

DEFRA. (2005). The appraisal of human related intangible impact of flooding, Joint DEFRA/EA Flood and Coastal Erosion - Risk Management $R \& D$ Programme.

Departemen Pekerjaan Umum. (1991). Standar SNI 0624051991 - Tata cara perencanaan teknik sumur resapan air hujan untuk lahan pekarangan, Yayasan LPMB: Bandung.

Dong, X., Chen, J., Zeng, S. \& Zhao, D. (2008a). Integrated assessment of urban drainage system under the framework of uncertainty analysis, Water Science and Technology, 57(8), p.12271234.

Dong, X., Zeng, S., Chen, J. \& Zhao, D. (2008b). An integrated assessment method of urban drainage system: A case study in Shenzhen City, China, Frontiers of Environmental Science \& Engineering in China, 2(2), p.150-156.

Eboli, L. \& Mazzulla, G. (2013). A multicriteria approach for analyzing railway service quality, Publication at the $92^{\text {nd }}$ Annual Meeting of the TRB,32 Washington, D.C.

Ellis, J.B., Deutsch, J.C., Mouchel, J.M., Scholes, L. \& Revitt, M.D. (2004) Multicriteria decision approaches to support sustainable drainage options for the treatment of highway and urban runoff, Science of the Total Environment, 334335 , p. 251-260.

Ellis, J.B., et al. (2006). The DayWater decision support approach to the selection of sustainable drainage systems: A multi-criteria methodology for BMP decision makers, Water Practice and Technology, 1(1), p.wpt2006002.

FAO. (1980). Drainage design factors. FAO Irrigation and Drainage Paper, 38, p.52.

Gill, S.E., Handley, J.F., Ennos, A.R. \& Pauleit, S. (2007). Adapting cities for climate change: The role of the green infrastructure, Built Environment, 33(1). 
Hapsari, R.I. \& Zenurianto, M. (2016). View of flood disaster management in Indonesia and the key solutions. American Journal of Engineering Research, 5(3), p. 140-151.

Hassana, M.F. Saman, M.Z.M., Sharif, S. \& Omara, B. (2012). An integrated MA-AHP approach for selecting the highest sustainability index of a new product, Procedia - Social and Behavioral Sciences, 57, p. 236-242.

Kennedy, S., Lewis, L., Sharp, E. \& Wong, S. (2007). Sustainable urban drainage systems (SUDS) More than a drainage solution?, Proceeding of Novatech.

Kirpich, Z.P. (1940). Time of concentration of small agricultural watersheds, Civil Engineering, 29(3), p. 174.

Loc, H.H., Huong, L.N.Q. Tue, N.N., Kusakabe, T. \& Shimizu, Y. (2015). Feasibility assessment of sustainable urban drainage systems (SUDS) in Ho Chi Minh City using an Analytic Hierarchy Process (AHP) approach, Proceeding of World Engineering Conference and Convention.

Martina, C., Ruperdb, Y. \& Legreta, M. (2007). Urban stormwater drainage management: The development of a multicriteria decision aid approach for best management practices, European Journal of Operational Research, 181(1), p. 338-349.

Millington, N., Das, S. \& Simonovic, S.P. (2011). The comparison of GEV, Log-Pearson type 3 and Gumbel distributions in theUpper Thames River watershed under Global Climate Models, Water Resources Research Report - Department of Civil and Environmental Engineering - The University of Western Ontario, 077.

Moghaddam, K.R. \& Karami, E. (2008). A multiple criteria evaluation of sustainable agricultural development models using AHP, Environment, Development and Sustainability, 10(4), p. 407426.
Pires, A., Chang, N.B. \& Martinho, G. (2011). An AHP-based fuzzy interval TOPSIS assessment for sustainable expansion of the solid waste management system in Setúbal Peninsula, Portugal, Resources, Conservation and Recycling.

Brouwer, C., Prins, B.K., Kay, M. \& Heibloem, M. (2001). Irrigation Water Management: Irrigation Methods, FAO - Land and Water Development Division.

Ready, R.C., Berger, M.C. \& Blomquist, G.C. Measuring amenity benefits from farmland: Hedonic pricing vs. contingent valuation, Growth and Change, 28(4), p. 438-458.

Rianawati, E. \& Sagala, S. (2014). Communal based flood mitigation measures in Bandung city, Working Paper Series of Resilience Development Initiative, 10.

Saaty, T.L. (1980). The Analytic Hierarchy Process, McGraw-Hill, New York.

Sunjoto, S. (2008). The recharge trench as a sustainable supply system. Journal of Environmental Hydrology, 16, p.11.

Suripin. (2004). Sistem Drainase Perkotaan yang Berkelanjutan, $1^{\text {st }}$ edition, Penerbit Andi, Yogyakarta.

Task Committee on Hydrology Handbook of Management Group D of ASCE. (1996). Hydrology Handbook, $2^{\text {nd }}$ Edition. American Society of Civil Engineers, New York.

Turner, R.K. \& Daily, G.C. (2008). The ecosystem services framework and natural capital conservation, Environmental and Resources Economics, 39(1), p. 25-35.

US-EPA. (2003). When are stormwater discharge regulated as class v wells, Class $V$ Guidance Documents for Owners, Operators and Regulatory Agencies.

Zhou, Q. (2014). A review of sustainable urban drainage systems considering the climate change and urbanization impacts, Water. 6, p. 976-992. 